\title{
Influence of storage conditions and market temperature on shelf-life and quality of Keitt mango ${ }^{1,2}$
}

\author{
Guillermo Fornaris-Rullán,, Rubén Guadalupe-Luna," \\ Carmen Chao de Báez and Noemí Díaz
}

\begin{abstract}
A study was conducted on 2 storage temperatures $\left(10.6^{\circ}\right.$ and $\left.13^{\circ} \mathrm{C}\right)$, 4 storage intervals $\left(1,2,3\right.$ and 4 weeks) and 2 market temperatures $\left(20^{\circ}\right.$ $\mathrm{C}$ or $27^{\circ} \mathrm{C}$ ) to assess differences in shelf-life and some quality components of Keitt mango, Mangifera indica L. Fruit exposed to the longer storage intervals showed a significant decrease in ripening time after storage under market conditions up to 4 days. This is also true for those stored at $13^{\circ} \mathrm{C}$ as compared to those stored at $10.6^{\circ} \mathrm{C}$, with a 2.64-day period difference. The higher storage temperature caused some increase in anthracnose and stem-end rot. The longer the storage interval, or the ripening time after storage under market conditions, the greater was the final weight loss.
\end{abstract}

\section{RESUMEN}

Influencia de las condiciones de almacenamiento y la temperatura de mercado sobre la duración y la calidad del mangó Keitt

Se hizo un estudio con dos temperaturas de almacenamiento $\left(10.6^{\circ} \mathrm{C}\right.$. y $13^{\circ} \mathrm{C}$.), cuatro intervalos de almacenamiento $(1,2,3$ y 4 semanas) y dos temperaturas de mercado $\left(20^{\circ}\right.$ y $27^{\circ} \mathrm{C}$.) para estimar las posibles diferencias en la tolerancia al almacenamiento $y$ en algunos componentes de calidad del mangó Keitt, Mangifera indica L. Las frutas almacenadas por más tiempo maduraron hasta $\mathbf{4}$ días más rápido una vez expuestas a las condiciones de mercado. Este acortamiento del tiempo fue significativo para las almacenadas a $13^{\circ} \mathrm{C}$. al compararse con las almacenadas a $10.6^{\circ}$ C. A $13^{\circ} \mathrm{C}$. aumentó el desarrollo del color de la superficie de la fruta. Hubo un aumento significativo en los índices de los síntomas de antracnosis y de pudrición del extremo apical de las frutas almacenadas por más de una semana. Mientras más prolongado el intervalo de almacenamiento - el tiempo después del almacenamiento para que éstas frutas maduren bajo condiciones de mercado, mayor es la pérdida final de peso.

\section{INTRODUCTION}

Among the tropical fruits grown in Puerto Rico, mango has been consistently showing the greatest economic growth rate during the past

'Manuscript submitted to Editorial Board 14 August 1989.

2This study was conducted under CBAG-28, Postharvest Technology of Tropical Fruits and Vegetables Produced in Puerto Rico.

${ }^{3}$ Assistant Horticulturist, Department of Horticulture.

${ }^{4}$ Horticulturist, Department of Horticulture.

"Associate Statistician, Statistics Section.

${ }^{6}$ Food Technologist, Laboratory of Food Technology. 
few years. The value of local production for the export market increased from $\$ 213,291$ in fiscal year $1983-84$, to $\$ 3,643,700$ in $1986-87$ (4). This trend is expected to continue. In order to be competitive in this or any other market, however, the high quality of mango fruits must be unimpaired.

At present, most of the local production is exported to Europe. Therefore, the fruits are shipped in refrigerated containers at approximately $10.6^{\circ} \mathrm{C}$. $\left(51^{\circ} \mathrm{F}\right)$ for some 15 days, which is the average in transit storage period from a local packing house to major European terminal markets. In many cases, the complete storage time period from harvest to arrival at the retail market might be 3 weeks or more, probably under suboptimal relative humidity conditions.

According to the United States Department of Agriculture, the best storage (or in-transit) conditions for mangos require a temperature of $13^{\circ}$ $\mathrm{C}\left(55^{\circ} \mathrm{F}\right)$, and a relative humidity of $85-90 \%$ for a period of 2 or 3 weeks $(1,3)$. Some cultivars could do well at $10^{\circ} \mathrm{C}\left(50^{\circ} \mathrm{F}\right)$ without showing chilling injury symptoms, but other cultivars such as Haden and Keitt will suffer $(1,3)$. Two of the postharvest factors influencing quality attributes of a given horticultural crop are the environmental temperature and the interval between harvesting and consumption, or harvesting to processing $(2,7)$.

The objective of this study was to determine possible effects of storage temperature $\left(10.6^{\circ} \mathrm{C}\right.$ or $\left.13^{\circ} \mathrm{C}\right)$, storage interval $(1,2,3$ and 4 weeks) and retail market temperature $\left(20^{\circ}\right.$ and $\left.27^{\circ} \mathrm{C}\right)$ on shelf-life, weight loss, skin color and decay symptoms of locally grown Keitt mangos.

\section{MATERIALS AND METHODS}

Mangos of the Keitt cultivar were obtained 15 August 1987 from a commercial packing house at a farm located in southern Puerto Rico. They were harvested at the mature-green stage, classified by size and packed in single-layer boxes for the export market. At this stage, all fruits were free of any anthracnose and stem-end rot symptoms. Sixtyfour single-layer boxes containing 7 fruits each, with an average net weight per box of $4.54 \mathrm{~kg}$, were sent to the Food Technology Laboratory in Rio Piedras. After weighing the fruits in each box, we stored half of the boxes at a temperature of $10.6^{\circ} \mathrm{C}\left(51^{\circ} \mathrm{F}\right)$ and the other half at $13^{\circ} \mathrm{C}$ $\left(55^{\circ} \mathrm{F}\right)$. In order to simulate possible suboptimal relative humidity conditions encountered in many storage rooms and refrigerated shipping containers, both groups were stored under a controlled relative humidity of approximately $75 \%$. Storage intervals of $1,2,3$ and 4 weeks were studied. After each storage period, 8 boxes were removed from the $10.6^{\circ}$ $\mathrm{C}$, and 8 from the $13^{\circ} \mathrm{C}$ storage rooms. Fruits in these boxes were weighed to measure in-storage weight loss. Four boxes from each group were exposed to an average market temperature of $20^{\circ} \mathrm{C}\left(68^{\circ} \mathrm{F}\right)$ in an 
air conditioned room, and the other four to an average market temperature of $27^{\circ} \mathrm{C}\left(80^{\circ} \mathrm{F}\right)$ under ambient conditions. Fruits were kept under one of these two market temperatures until ripening, i.e., just starting to soften (consumer eating stage). The combinations of 2 storage temperatures, 4 storage intervals and 2 market temperatures represent the 16 treatments under evaluation, each of them having 4 replications (boxes).

Upon reaching the ripe stage, fruits from each box were weighed again to determine final weight loss, and rated for skin color and decay $(5,6)$. Ripening time after storage was determined by manually evaluating fruit firmness every 2 or 3 days, until the ripe stage. Skin color was subjectively determined and rated on a scale of 1 through 5 , based on the percentage of nongreen surface area: $\lambda=0 \%$ (green); $2=1-25 \% ; 3=$ $26-50 \% ; 4=50-75 \%$; and $5=76-100 \%$ nongreen. Decay was visually rated by the percentage of surface area affected by anthracnose, Colletotrichum gloeosporioides, and by the radius of the area affected by stemend rot, Diplodia natalensis (5). These are considered as the two most important postharvest diseases in mangos $(8,9)$. The scoring for decay was as follows:

$\begin{array}{lcc}\text { Rating } & \begin{array}{c}\text { Anthracnose } \\ \text { (\% surface area) }\end{array} & \begin{array}{c}\text { Slem-endrot } \\ \text { (mm from stem) }\end{array} \\ 0 \text { (none) } & 0 & 0 \\ 1 \text { (trace) } & \leqq 2 & \leqq 3 \\ 2 \text { (slight) } & 3-10 & 4-13 \\ 3 \text { (moderate) } & 11-20 & 14-25 \\ 4 \text { (severe) } & >20 & >27\end{array}$

\section{RESULTS AND DISCUSSION}

The interval had a significant effect on all parameters under evaluation. The two most affected were in storage weight loss and ripening time after storage. In both cases, differences were statistically significant among all values corresponding to the different storage intervals. The fruits exposed to a longer storage interval showed a significant increase for in storage weight loss, up to a difference between the mean values of $2.43 \%$ (table 1 ). The days required after storage for the fruits to achieve the ripe stage significantly decreased at longer storage periods, with differences of up to 4 days. The final weight loss at the ripe stage was similar for the 1-week and 2-week storage, but lower than values for the other two storage periods. The lower values for surface color and stem-end rot indices determined at the ripe stage occurred after 1-week storage, and no significant differences were observed among the other storage times (table 2). The lowest anthracnose index occurred after 1-week storage. The 3 -week storage time showed values similar to those of 4-week storage. 
TARLE 1.-Effects of storage interval, storage temperature and marlet temperature on in storage weight loss, final weight loss and ripening time of Keitt. mango

\begin{tabular}{cccc}
\hline Main effects & $\begin{array}{c}\text { In storage } \\
\text { weight loss }\end{array}$ & $\begin{array}{c}\text { Final } \\
\text { weight loss' }\end{array}$ & $\begin{array}{c}\text { Ripening time } \\
\text { after storage }\end{array}$ \\
\hline Storage interval & $\%$ & $\%$ & Days \\
\hline 1 wk & $2.05 \mathrm{~d}^{2}$ & $6.15 \mathrm{~b}$ & $7.00 \mathrm{a}$ \\
$2 \mathrm{wk}$ & $2.74 \mathrm{c}$ & $6.34 \mathrm{~b}$ & $5.97 \mathrm{~b}$ \\
$3 \mathrm{wk}$ & $3.55 \mathrm{~b}$ & $7.44 \mathrm{a}$ & $4.75 \mathrm{c}$ \\
$4 \mathrm{wk}$ & $4.48 \mathrm{a}$ & $7.46 \mathrm{a}$ & $3.00 \mathrm{~d}$ \\
Storage temp. & & & \\
\hline $10.6^{\circ} \mathrm{C}$ & $2.63 \mathrm{~b}$ & $7.40 \mathrm{a}$ & $6.50 \mathrm{a}$ \\
$13.0^{\circ} \mathrm{C}$ & $3.77 \mathrm{a}$ & $6.29 \mathrm{~b}$ & $3.86 \mathrm{~b}$ \\
Market temp. & & & \\
\hline $20.0^{\circ} \mathrm{C}$ & $3.21 \mathrm{a}^{3}$ & $7.23 \mathrm{a}$ & $5.57 \mathrm{a}$ \\
$27.0^{\circ} \mathrm{C}$ & $3.18 \mathrm{a}$ & $6.46 \mathrm{~b}$ & $4.79 \mathrm{~b}$ \\
\hline
\end{tabular}

'At fruit ripening; i.e., just starting to soften (consumer eating stage).

'Mean separation of main effects within columns by Duncan's multiple range test at the $5 \%$ level.

These are the in storage weight loss values of the fruits previous to being exposed to the $20.0^{\circ} \mathrm{C}$ and to the $27.0^{\circ} \mathrm{C}$ market temperatures, respectively.

TABLE 2.-Effects of storage interval, storage temperature and market temperature on surface color, anthracnose and stem-end rot of Keitt mango at the ripe stage

\begin{tabular}{cccc}
\hline Main effects & $\begin{array}{c}\text { Surface color } \\
\text { index }\end{array}$ & $\begin{array}{c}\text { Anthracnose } \\
\text { index }\end{array}$ & $\begin{array}{c}\text { Stem-end rot } \\
\text { index }^{3}\end{array}$ \\
\hline $\begin{array}{cccc}\text { Storage interval } \\
\text { I wk }\end{array}$ & $4.11 \mathrm{~b}^{4}$ & $0.55 \mathrm{c}$ & $0.04 \mathrm{~b}$ \\
$2 \mathrm{wk}$ & $4.44 \mathrm{a}$ & $1.26 \mathrm{~b}$ & $0.46 \mathrm{a}$ \\
$3 \mathrm{wk}$ & $4.52 \mathrm{a}$ & $2.39 \mathrm{a}$ & $0.44 \mathrm{a}$ \\
$4 \mathrm{wk}$ & $4.64 \mathrm{a}$ & $2.20 \mathrm{a}$ & $0.66 \mathrm{a}$ \\
Storage temp. & & & \\
\hline $10.6^{\circ} \mathrm{C}$ & $4.20 \mathrm{~b}$ & $1.70 \mathrm{a}$ & $0.38 \mathrm{a}$ \\
$13.0^{\circ} \mathrm{C}$ & $4.66 \mathrm{a}$ & $1.50 \mathrm{a}$ & $0.43 \mathrm{a}$ \\
Market temp. & & & \\
\hline $20.0^{\circ} \mathrm{C}$ & $4.37 \mathrm{a}$ & $1.69 \mathrm{a}$ & $0.43 \mathrm{a}$ \\
$27.0^{\circ} \mathrm{C}$ & $4.48 \mathrm{a}$ & $1.50 \mathrm{a}$ & $0.38 \mathrm{a}$ \\
\hline
\end{tabular}

Surface color index: $1=0 \%$ (green); $2=1-25 \% ; 3=26-50 \% ; 4=51-75 \% ; 5=76-100 \%$ non-green.

'Anthracnose index: surface area affected, $0=0 \% ; 1 \leqq 2 \% ; 2=3-10 \% ; 3=11-20 \% ; 4>$ $20 \%$.

3Stem-end rot index: radius in $\mathrm{mm}$ of area affected, $0=$ none; $1 \leqq 3 \mathrm{~mm} ; 2=4-13 \mathrm{~mm}$; $3=14-25 \mathrm{~mm} ; 4>25 \mathrm{~mm}$.

"Mean separation of main effects within columns by Duncan's multiple range test at the $5 \%$ level. 
When the two storage temperature effects were compared, statistically significant differences were observed for in storage weight loss, final weight loss, ripening time after storage, and surface color index (tables 1 and 2). In storage weight loss was $1.14 \%$ higher under $13.0^{\circ} \mathrm{C}$ than under $10.6^{\circ} \mathrm{C}$ (table 1 ) and the final weight loss (at the ripe stage) was $1.11 \%$ lower for the fruits under a storage temperature of $13.0^{\circ} \mathrm{C}$ than under $10.6^{\circ} \mathrm{C}$. This opposite storage temperature effect observed on these two parameters might be related to differences in ripening time after storage, since the fruits which had been exposed to a storage temperature of $13.0^{\circ} \mathrm{C}$ achieved the ripe stage 2.64 days before those stored under $10.6^{\circ} \mathrm{C}$, with less time exposed to market conditions. At the ripe stage, the fruits previously stored under $13.0^{\circ} \mathrm{C}$ showed a significantly higher surface color index. Storage temperatures had no significant effect on anthracnose and stem-end rot indices.

A statistically significant decrease was evident in ripening time after storage and final weight loss of the fruits at the higher of the two market temperatures used in this experiment (table 1 ). At $27.0^{\circ} \mathrm{C}$ the ripening: time after storage was 0.78 days less and the final weight loss was $0.77 \%$ less than at $20^{\circ} \mathrm{C}$. There was no significant effect of market temperature on other parameters (tables 1 and 2 ).

There was a significant interaction between storage interval, storage temperature and market temperature on the ripening time after storage (table 3). At the $10.6^{\circ} \mathrm{C}$ storage temperature, there were significant differences only at the $27.0^{\circ} \mathrm{C}$ market temperature after 2-week storage. At the $13.0^{\circ} \mathrm{C}$ storage temperature, differences for ripening time after storage were observed after the 1-week storage period at the two market temperatures. This finding suggests that the storage temperature is the most influential factor on the ripening time after storage.

TABLE 3.-Interaction of storage temperature, market temperature, and storage interval on ripening time after storage of the Keitt mango

\begin{tabular}{llllll}
\hline & Market & \multicolumn{4}{c}{ Ripening time after storage (days) } \\
\cline { 4 - 6 } $\begin{array}{l}\text { Storage } \\
\text { temp. } \\
\left({ }^{\circ} \mathrm{C}\right)\end{array}$ & $\begin{array}{l}\text { 1-week } \\
\left({ }^{\circ} \mathrm{C}\right)\end{array}$ & $\begin{array}{l}\text { 2-week } \\
\text { storage }\end{array}$ & $\begin{array}{l}\text { 3-week } \\
\text { storage }\end{array}$ & $\begin{array}{l}\text { 4-week } \\
\text { storage }\end{array}$ \\
\hline $10.6^{\circ}$ & $20.0^{\circ}$ & $7.00 \mathrm{a}^{2}$ & $8.00 \mathrm{a}$ & $7.00 \mathrm{a}$ & $7.00 \mathrm{a}$ \\
& $27.0^{\circ}$ & $7.00 \mathrm{a}$ & $7.00 \mathrm{a}$ & $4.00 \mathrm{~b}$ & $5.00 \mathrm{~b}$ \\
$13.0^{\circ}$ & $20.0^{\circ}$ & $7.00 \mathrm{a}$ & $4.50 \mathrm{~b}$ & $4.00 \mathrm{~b}$ & $-{ }^{2}$ \\
& $27.0^{\circ}$ & $7.00 \mathrm{a}$ & $4.30 \mathrm{~b}$ & $4.00 \mathrm{~b}$ & - \\
\hline
\end{tabular}

'Means in columns and rows separated by Duncan's multiple range test at the $5 \%$ level.

${ }^{2} \mathrm{No}$ values for ripening time after the 4-week storage period under $13.0^{\circ} \mathrm{C}$, since the fruits were already at the ripe stage (i.e., just starting to soften) when evaluated. 
Table 4 shows the significant interaction between storage temperature and market temperature on final weight loss. There is a general tendendy for the fruit to decrease in final weight as the storage time increases. Significant differences were found in the 1-week storage and 2-week storage periods between the two storage temperatures.

A significant interaction observed between the storage and the market temperatures on the final weight loss is shown below. The greatest final weight loss occurred in the $10.6^{\circ} \mathrm{C}$ storage temperature and the $20.0^{\circ} \mathrm{C}$ market temperature combination. Differences were significant when compared to the other three. This combination also showed the longest ripening time after storage, which might explain the greatest value in final weight loss.

\begin{tabular}{lcc} 
Storage temp. & \multicolumn{2}{c}{ Final weight loss (\%) } \\
\cline { 2 - 3 }$\left({ }^{\circ} \mathrm{C}\right)$ & $\begin{array}{c}20.0^{\circ} \mathrm{C} \\
\text { Market temp. }\end{array}$ & $\begin{array}{c}27.0^{\circ} \mathrm{C} \\
\text { Market temp. }\end{array}$ \\
$10.6^{\circ}$ & $8.08 \mathrm{a}^{8}$ & $6.73 \mathrm{~b}$ \\
$13.0^{\circ}$ & $6.38 \mathrm{c}$ & $6.20 \mathrm{c}$
\end{tabular}

The following tabulation shows that another parameter affected by a significant interaction between the storage and the market temperature is the surface color index, as well as differences between mean values for surface color index of the fruits exposed to the lower storage temperature $\left(10.6^{\circ} \mathrm{C}\right)$ and the two market temperatures $\left(20.0^{\circ} \mathrm{C}\right.$ and $\left.27.0^{\circ} \mathrm{C}\right)$. These mean values also showed significant differences when compared to the higher values in the fruits stored at $13.0^{\circ} \mathrm{C}$ under each of the two market temperatures.

TABLE 4.-Interaction of storage temperature and storage interval on final weight loss of Keitt mango'

\begin{tabular}{lllll}
\hline \multirow{2}{*}{$\begin{array}{l}\text { Storage } \\
\text { temp. } \\
\left({ }^{\circ} \mathrm{C}\right)\end{array}$} & \multicolumn{4}{c}{ Final weight loss (\%) } \\
\cline { 2 - 5 } & $\begin{array}{l}\text { 1-week } \\
\text { storage }\end{array}$ & $\begin{array}{l}\text { 2-week } \\
\text { storage }\end{array}$ & $\begin{array}{l}\text { 3-week } \\
\text { storage }\end{array}$ & $\begin{array}{l}\text { 4-week } \\
\text { storage }\end{array}$ \\
\hline $10.6^{\circ}$ & $5.60 \mathrm{c}^{2}$ & $6.76 \mathrm{~b}$ & $7.48 \mathrm{~b}$ & $9.78 \mathrm{a}$ \\
$13.0^{\circ}$ & $6.69 \mathrm{de}$ & $5.91 \mathrm{ef}$ & $7.41 \mathrm{bd}$ & $-{ }^{-3}$ \\
\hline
\end{tabular}

\footnotetext{
'At the ripe stage, i.e., just starting to soften.

'Means within columns and rows separated by Duncan's multiple range test at the $5 \%$ level.

${ }^{3}$ No mean value is shown because at the end of the 4-week storage period under $13.0^{\circ}$ $\mathrm{C}$, fruits have already achieved the ripe stage. Therefore, the only value for weight loss is the in storage weight loss since these fruits were not exposed to market conditions.
} 
Storage temp.

$\left({ }^{\circ} \mathrm{C}\right)$

$10.6^{\circ}$

$13.0^{\circ}$
Surface color index

$$
\begin{array}{cc}
20.0^{\circ} \mathrm{C} & 27.0^{\circ} \mathrm{C} \\
\text { Markel temp. } & \text { Markel temp. }
\end{array}
$$

$\begin{array}{ll}4.04 \mathrm{a}^{\mathrm{s}} & 4.36 \mathrm{~b} \\ 4.70 \mathrm{c} & 4.61 \mathrm{c}\end{array}$

The ripening time after storage of Keitt mangos exposed to the longer storage intervals decreased under market conditions up to 4 days. This decrease is also true for the fruits stored under $13.0^{\circ} \mathrm{C}$ when compared to those stored at $10.6^{\circ} \mathrm{C}$, showing a 2.64-day period difference. At the same time, the higher storage temperature caused some increase in nongreen surface color. There was a significant increase in the anthracnose and stem-end rot indices on fruit stored for more than 1 week. The longer storage interval, or the ripening time after storage (as an effect of the lower storage and/or market temperature), the greater the final weight loss.

\section{LITERATURE CITED}

1. Hardenburg, R. E., A. E. Watada and C. Y. Wang, 1986. The commercial storage of fruits, vegetables, and florist and nursery stocks. USDA Agric. Handbk. No. 66, p. 44.

2. Kader, A. A., 1985. Quality factors: definition and evaluation for fresh horticultural crops, p. 119. In: Kader, A. A., R. F. Kasmire, F. G. Mitchell, M. S. Reid, N. F. Sommer and J. F. Thompson. Postharvest Technology of Horticultural Crops. Univ. Calif., Div. of Agric. \& Nat. Resources, Special Publ. 3311.

3. McGregor, B. M., 1987. Tropical products transport handbook. USDA Agric. Handbk. No. 668 , p. 101.

4. Mendoza, M., 1989. Frutales, p. 154. In: Empresas Agrícolas de Puerto Rico. Dep. Agric. Econ. and Sociol., Coll. Agric. Sci. Univ. P. R.

5. Miller, W. R., D. H. Spalding and P. W. Hale, 1986. Film wrapping mangoes at advancing stages of post-harvest ripening. Trop. Sci. 26: 9-17.

6. - - P. W. Hale, D. H. Spalding and P. Davis, 1983. Quality and decay of mango fruit wrapped in heat-shrinkable film. HortScience 18: 957-58.

7. Rodriguez, R., B. L. Raina, E. B. Pantastico and M. B. Bhatti, 1975. Quality of raw materials for processing, p. 482. In: Pantastico, E. B. (Ed). Postharvest physiology, Handling and Utilization of Tropical and Subtropical Fruits and Vegetables. AVI Publ, Co., Westport, CT.

8. Smooth, J. J., L. G. Houck and H. B. Johnson, 1971. Market diseases of citrus and other subtropical fruits. USDA Agric. Handbk. No. 398, p. 70-72.

9. Sommer, N. F., 1985. Strategies for control of postharvest diseases of selected commodities, p. 97. In: Kader, A. A., R. F. Kasmire, F. G. Mitchell, M. S. Reid, N. F. Sommer and J. F. Thompson. Postharvest technology of Horticultural Crops. Univ. Calif., Div. of Agric. \& Nat. Resources, Special Publ. 3311.

${ }^{7}$ Surface color index: $1=0 \%$ (green); $2=1-25 \% ; 3=26-50 \% ; 4=51-75 \% ; 5=76-100 \%$ non-green. 